\title{
Student's Self-Assessment Regarding the Clinical Skills in Forensic Medicine
}

\author{
Taufik Suryadi $^{1}$, Kulsum Kulsum ${ }^{2}$ \\ ${ }^{1}$ Department of Forensic Medicine and Medicolegal, Faculty of Medicine, Universitas Syiah Kuala, Banda \\ Aceh, Indonesia \\ ${ }^{2}$ Department of Anesthesiology and Intensive Therapy, \\ Faculty of Medicine, Universitas Syiah Kuala, Banda Aceh, Indonesia \\ taufiksuryadi@unsyiah.ac.Id
}

\begin{abstract}
In the learning process in forensic medicine clinical rotation, a measurable and standardized evaluation system is needed. The preliminary survey is undertaken to assess the ability of the student in clinical skills in rotation of forensic medicine. This survey was carry out in the Faculty of Medicine, Universitas Syiah Kuala, Banda Aceh, Indonesia. The instrument used in this study was a questionnaire. Data was analyzed is done manually. As many as 81 medical students were included in the survey $(20$ male and 61 female). The average student score is based on survey 3.40, while the average academic value was given by the lecturer is 3.49. The survey was invalid with sensitivity 0.519, and specificity 0.593 (value $<0,6$ ). In this survey, found the validity of student self-assessment not valid in determining the ability of clinical skills, it is influenced by several factors of objectivity and subjectivity of assessment both in terms of students and lecturers. In general, student's clinical skills in accordance with the achievement of competency in clinical rotation of forensic medicine.
\end{abstract}

Keywords: clinical skills; forensic medicine; student's self-assessment

\section{Introduction}

The success of a medical education process can be determined from the results of the assessment. Evaluation programs in medical education are multidimensional in nature involving all information in the learning process and learning outcomes, which can be objective and subjective (Schiekirka et al., 2012). In general, the education system aims to produce a critical thinker who can analyze and evaluate his abilities. Self-assessment is now a major component in the learning process because medical students provide information about their learning outcomes and reflect on themselves regarding the clinical abilities they have mastered (Sharma et al.,2016).

By using the self-assessment method, a student can find out his strengths and weaknesses in learning. Student self-assessment can be done by comparing the ability of self with the ability of other students (peers) at this time, or with the ability of previous students or by using measurable value standards. Lecturer assessment can be used as a gold standard because it is considered valid and reliable in assessing student learning (Khoiriyah et al., 2015). Selfassessment seems well suited for in implementation into clinical learning because in clinical learning can be done with the approach of an integrated Problem Based learning (PBL) and Case-Based Learning (CBL). In integrated PBL and CBL, students are required to find the learning methods they like (self-directed learning) so that later students can make selfevaluations for the success of their learning process. In applying self-assessment, students need to reopen the learning experience document during the clinical clerkship, information obtained from logbook, activity report books, case reports, and scientific articles that have been made. The existence of complete documents will be very helpful for self-assessment and contribute to improving the quality of clinical education for students (Khoiriyah et al., 2015; Al Haqwi \& Taha, 2015).

But in reality, some literature states that most of the research still focuses on the 
'accuracy' of self-assessment and shows that students are not accurate in assessing their performance. While there is little research stating that self-assessment can improve student learning (Khoiriyah et al., 2015). The benefits of self-assessment summarized by Spiller: (1) an easy way for students to self-assess the progress of their learning outcomes, (2) increase awareness of the needs learning in the future, (3) increasing learning motivation, (4) students can identify strengths and weaknesses in learning, (5) independence in learning can be improved, (6) students can be responsible for lifelong learning, and, (7) help students better understand about problems on specific topics (Spiller, 2012).

Self-assessment is still rarely used in assessing competency achievement because it is likely related to its validity and reliability that still needs to be tested (Muth'im, 2016). Instruments for self-assessment must be designed with a broader learning context and not only focus on specific domains such as knowledge acquisition but also must include aspects of skills and professionalism (Khoiriyah et al., 2015). So that a scientific study is needed that discusses self-assessment to determine the validity of a student's self-assessment of the achievement of competencies with a gold standard of academic value given by the lecturer.

\section{Methods}

A preliminary survey of medical students was carry out at the Faculty of Medicine, Syiah Kuala University, Banda Aceh, Indonesia from February to March 2020. The participants were students of the Faculty of Medicine at Syiah Kuala University who had passed the clinical rotation of forensic medicine. During data collection, all respondents agreed to participate by signing the consent sheet before answering the questionnaire. The purpose of this survey is to investigate the ability of student's clinical skills by using self-assessment. During the survey, respondents were asked 22 questions regarding the ability of respondents to handle clinical problems that had been studied previously by filling in the competency level column listed on the questionnaire sheet according to the competency standards of Indonesian doctors (CSID) 2012 was set by the Indonesian Medical Council (IMC). The results of the average level of clinical ability are then compared with the academic value was given by the lecturer. Descriptive data analysis was done manually to determine the validity of student's ability on clinical skills by using self-assessment determined by the sensitivity and specificity.

\section{Results and Discussion}

The survey was conducted on medical students in Medical faculty of Universitas Syiah Kuala as many as 81 respondents, with characteristics based on academic value, age and gender presented in table 1 .

Table 1. Characteristic of Respondents $(n=81)$

\begin{tabular}{|l|l|c|c|}
\hline $\begin{array}{c}\text { Characteristic of } \\
\text { respondents }\end{array}$ & \multicolumn{1}{|c|}{ Category } & Frequency & Percentage \\
\hline \multirow{2}{*}{ Sex } & Male & & \\
\cline { 2 - 4 } & Female & 20 & $24,7 \%$ \\
\hline \multirow{2}{*}{ Age } & & 61 & $75,3 \%$ \\
\cline { 2 - 4 } & 22 year & 7 & $8,6 \%$ \\
\cline { 2 - 4 } & 23 year & 50 & $61,7 \%$ \\
\cline { 2 - 4 } & 24 year & 19 & $23,6 \%$ \\
\hline
\end{tabular}


Budapest International Research in Exact Sciences (BirEx) Journal Volume 2, No 2, April 2020, Page: 241-247 e-ISSN: 2655-7827 (Online), p-ISSN: 2655-7835(Print) www.bircu-journal.com/index.php/birex emails: birex.journal@gmail.com

\begin{tabular}{|l|l|c|c|}
\hline & 25 year & 4 & $4,9 \%$ \\
\cline { 2 - 4 } & 26 year & 1 & $1,2 \%$ \\
\hline \multirow{3}{*}{ Academic value } & A (average 4,00) & 24 & $29,6 \%$ \\
\cline { 2 - 4 } & AB (average 3,50) & 32 & $39,5 \%$ \\
\cline { 2 - 4 } & B (average 3,00) & 25 & $30,9 \%$ \\
\hline
\end{tabular}

A total of 81 people respondents have filled with the complete questionnaire $(100 \%$ response rate). Respondents who participated in this study were medical students who entered in year 2014 as student of undergraduate medical education. In general respondents who participated in this survey were female $(75,3 \%)$. The average of participant age was 23,28 , median and modus 23,00, age 22 minimum, and 26 maximum. The average of academic value was 3,49 , median and modus 3,50 .

Table 2. Statements of Students' Ability to the Clinical Skills in Clinical Forensic

\begin{tabular}{|c|l|c|c|c|c|}
\hline $\begin{array}{c}\text { Clinical } \\
\text { skills }\end{array}$ & \multicolumn{1}{|c|}{ Student's statement } & $\begin{array}{c}\text { Yes } \\
(\mathrm{n}=81)\end{array}$ & $\begin{array}{c}\text { Percentage } \\
(\%)\end{array}$ & $\begin{array}{c}\text { No } \\
(\mathrm{n}=81)\end{array}$ & $\begin{array}{c}\text { Percentage } \\
(\%)\end{array}$ \\
\hline \multirow{5}{*}{$\begin{array}{c}\text { Clinical } \\
\text { forensic }\end{array}$} & $\begin{array}{l}\text { I able to examine live victims in } \\
\text { cases traffic accident }\end{array}$ & 80 & 98,8 & 1 & 1,2 \\
\cline { 2 - 6 } & $\begin{array}{l}\text { I able to examine live victims in } \\
\text { cases blunt and sharp violence }\end{array}$ & 80 & 98,8 & 1 & 1,2 \\
\cline { 2 - 6 } & $\begin{array}{l}\text { I able to examine live victims in } \\
\text { cases gunshot wounds }\end{array}$ & 77 & 95,1 & 4 & 4,9 \\
\cline { 2 - 6 } & $\begin{array}{l}\text { I able to examine live victims in } \\
\text { cases sexual offences }\end{array}$ & 71 & 87,7 & 10 & 12,3 \\
\cline { 2 - 6 } & $\begin{array}{l}\text { I able to examine live victims in } \\
\text { cases poisoning }\end{array}$ & 69 & 85,2 & 12 & 14,8 \\
\cline { 2 - 6 } & $\begin{array}{l}\text { I able to examine live victims in } \\
\text { cases violence against children }\end{array}$ & 73 & 90,1 & 8 & 9,9 \\
\cline { 2 - 6 } & $\begin{array}{l}\text { I able to examine live victims in } \\
\text { cases domestic violence }\end{array}$ & 77 & 95,1 & 4 & 4,9 \\
\hline
\end{tabular}

Clinical forensics in Indonesia is a mandatory competency that must be possessed by all general practitioners. Clinical forensics contains the handling of cases of living victims such as cases of violence against children, domestic violence, and sexual violence. A general practitioner must be able to make a clinical forensic examination report in the form of a visum et repertum. Clinical forensics is performed only if requested by a police investigator (Gopalakrishnan et al., 2016). In this study, average 92,9\% students stated that they could master clinical forensic skills in all cases. This is in accordance with research conducted by Fouche et al, stating that teaching/learning during clinical rotation can increase physicians' knowledge of clinical forensics (Fouche et al., 2019).

Table 3. Statements of Students' Ability to the Clinical Skills in Forensic Pathology

\begin{tabular}{|c|l|c|c|c|c|}
\hline $\begin{array}{c}\text { Clinical } \\
\text { skills }\end{array}$ & \multicolumn{1}{|c|}{ Student's statement } & $\begin{array}{c}\text { Yes } \\
(\mathrm{n}=81)\end{array}$ & $\begin{array}{c}\text { Percentage } \\
(\%)\end{array}$ & $\begin{array}{c}\text { No } \\
(\mathrm{n}=81)\end{array}$ & $\begin{array}{c}\text { Percentage } \\
(\%)\end{array}$ \\
\hline \multirow{5}{*}{} & $\begin{array}{l}\text { I able to examine dead victims in } \\
\text { cases traffic accident }\end{array}$ & 77 & 95,1 & 4 & 4,9 \\
\cline { 2 - 6 } & $\begin{array}{l}\text { I able to examine dead victims in } \\
\text { cases blunt and sharp violence }\end{array}$ & 74 & 91,3 & 7 & 8,7 \\
\cline { 2 - 6 } & $\begin{array}{l}\text { I able to examine dead victims in } \\
\text { cases sexual offences }\end{array}$ & 68 & 83,9 & 13 & 16,1 \\
\hline
\end{tabular}


emails: birex.journal@gmail.com

\begin{tabular}{|l|l|c|c|c|c|}
\hline $\begin{array}{l}\text { Forensic } \\
\text { pathology }\end{array}$ & $\begin{array}{l}\text { I able to examine dead victims in } \\
\text { cases poisoning }\end{array}$ & 74 & 91,3 & 7 & 8,7 \\
\cline { 2 - 5 } & $\begin{array}{l}\text { I able to examine dead victims in } \\
\text { cases asphyxia }\end{array}$ & 68 & 83,9 & 13 & 16,1 \\
\cline { 2 - 5 } & $\begin{array}{l}\text { I able to examine live victims in } \\
\text { cases infanticide }\end{array}$ & 69 & 85,2 & 12 & 14,8 \\
\cline { 2 - 5 } & $\begin{array}{l}\text { I able to examine dead victims in } \\
\text { cases criminal abortion }\end{array}$ & 66 & 81,5 & 15 & 18,5 \\
\cline { 2 - 5 } & $\begin{array}{l}\text { I able to examine dead victims in } \\
\text { cases sudden death }\end{array}$ & 65 & 80,2 & 16 & 19,8 \\
\hline & $\begin{array}{l}\text { I able to examine forensic } \\
\text { identification }\end{array}$ & 76 & 93,8 & 5 & 6,2 \\
\hline
\end{tabular}

Forensic pathology is the branch of forensic medicine most often studied by medical students because forensic medicine used to examine dead victims, autopsy practice and determine the cause of death (Kishor, 2014). The use of autopsy for learning anatomy and forensic pathology is well known throughout the world (Andrade et al., 2009). But according to CSID 2012, autopsy is not the main competency that must be possessed by general practitioners. In this study, what was asked of respondents was the ability to carry out external examinations of dead victims and average $87,4 \%$ students stated that they could master forensic pathology skills in all cases.

Table 4. Statements of Students' Ability to the Clinical Skills in Medicolegal

\begin{tabular}{|c|c|c|c|c|c|}
\hline $\begin{array}{c}\text { Clinical } \\
\text { skills }\end{array}$ & Student's statement & $\begin{array}{c}\text { Yes } \\
(\mathrm{n}=81)\end{array}$ & $\begin{array}{l}\text { Percentage } \\
(\%)\end{array}$ & $\begin{array}{c}\text { No } \\
\mathrm{n}=81)\end{array}$ & $\begin{array}{l}\text { Percentage } \\
(\%)\end{array}$ \\
\hline \multirow{6}{*}{ Medicolegal } & $\begin{array}{l}\text { I able performed a medicolegal } \\
\text { procedures }\end{array}$ & 78 & 96,3 & 3 & 4,7 \\
\hline & $\begin{array}{l}\text { I able to make a forensic medical } \\
\text { report }\end{array}$ & 81 & 100 & 0 & 0 \\
\hline & $\begin{array}{l}\text { I able to make a medical } \\
\text { certificate }\end{array}$ & 80 & 98,8 & 1 & 1,2 \\
\hline & I able to issue a death certificate & 64 & 79,0 & 17 & 21,0 \\
\hline & $\begin{array}{l}\text { I able to provide an expert } \\
\text { statement }\end{array}$ & 70 & 86,4 & 11 & 13,6 \\
\hline & $\begin{array}{l}\text { I able to provide information to } \\
\text { the police }\end{array}$ & 64 & 79,0 & 17 & 21,0 \\
\hline
\end{tabular}

Medicolegal is a competency that needs to be studied by medical students in the clinical rotation of forensic medicine. Comprehensive medicolegal management is needed to ensure that forensic medical examinations do not only relate to a living victim or deceased, but also contain ethical responsibility and human interest for the victim and relatives. Another issue of medicolegal is the ability of doctors to produce quality reports and provide adequate expert testimony (Perera, 2013). The expert opinion given must be informative, reasoned, have evidence value, valid and rational. A medicolegal analysis approach by determining the nature and probability of a relationship between cause and effect of an event (Meilia et al., 2020). In this study, average $89,9 \%$ students stated that they could master medicolegal skills in all cases.

The results of this study are in line with IMC expectations so that students can handle clinical problems with levels 3 and 4 . Thus there are $90 \%$ of students have believed that he has clinical skills levels 3 and 4 . The students must master three component competency during clinical rotation of forensic medicine namely issuing visum et repertum, examination in case of 
blunt and sharp violence, and external postmortem examination. As many as $100 \%$ of students stated that they were able to make a forensic medical report in form of visum et repertum, as many as $98,9 \%$ of students said they were able to carry out examinations of living victims in case of blunt and sharp violence and as many as $95,1 \%$ of students said they were able to examine victims of death in case of traffic accident.

The competency component that must be achieved by students is medicolegal, forensic clinic and forensic pathology. Judging from tables 2,3 and 4, students' perceptions of their abilities are good, students are confident that they can perform the medical skills targeted by CSID 2012. The expected level of competence is level 4 (able to do independently) dan level 3 (able to demonstrate), while difficult cases can be done up to level 2 (understanding clinical reasoning and problem solving) or level 1 (knowing skills theory). If it is analogous that level 3 is equivalent to ability with academic grade B, and level 4 is equivalent to ability with academic grade A, a comparison can be made between the average results of student grades and student academic grades given by lecturers. The unique thing is that the results of the students' self-assessment (mean 3,40) are lower than those of the lecturer with a mean of 3.49.

Table 5: Comparison between self-Assessment by the Student with Lecturer Score

\begin{tabular}{|l|c|c|c|c|}
\hline \multirow{2}{*}{$\begin{array}{c}\text { Student scored by } \\
\text { self-assessment }\end{array}$} & \multicolumn{2}{|c|}{ Lecturer score } & \multicolumn{2}{|c|}{} \\
\cline { 2 - 5 } & High & Low & Total (n) & Statistic values \\
\hline High & 28 & 11 & 39 & $\begin{array}{l}\text { The sensitivity is } 0.519, \text { the } \\
\text { specificity is } 0.593 .\end{array}$ \\
\hline Low & 26 & 16 & 42 & \\
\hline Total & 54 & 27 & 81 & \\
\hline
\end{tabular}

$*$ cut of point 3,45, low category $=1.96-3,45$ and high category $=3.46-4.00$

Scores given by students regarding clinical skills vary between 1,96 and 4.00, with an average of 3.40. While the score of students provided lecturers ranged from 3,00 -4.00 and an average of 3.49. From the two averages the cut-off point is 3,45 . According to the cut-off point: the data can be categorized as low category $=1.96-3.45$ and high category $=3,46$ 4,00 (Table 5). From the statistical calculation, it was found that the sensitivity is 0.519 , the specificity is 0.593. Interpretations in this study: (1) student self-assessment methods are able to provide positive results of $51,9 \%$ in determining competency achievement compared to lecturer ratings, meaning that students' self-assessment tests are less sensitive in determining competency outcomes, (2) self-assessment methods students are able to give negative results (exclusion) of $59,3 \%$ in determining competency achievement compared to lecturer ratings, meaning that students' self-assessment tests are less specific in determining competency achievement.

By paying attention to the conditions, the results of a student's self-assessment is not valid because they have low sensitivity and specificity. Validity is measured by sensitivity and specificity, if the value $<0,6$ then the validity is low. This is also supported by the results of student self-assessments that are relatively the same as those of lecturers, judging by the average score given, which is 3.40 versus 3.49. Analysis of the absence of these differences because between the results of student self-assessment with the assessment of lecturers do not disagree that there are 44 respondents $(54,3 \%)$ have the same assessment compared with 37 respondents $(45,7 \%)$ have differences in the assessment. From these data, it can be said that the statistical test is no less significant difference with a value of agreement 0.54 still below the valid value $<0.6$ (Muth'im, 2016).

The score given by the lecturer is higher than the score given by the student in self- 
assessment can be caused by several factors: (1) lecturer assessment has several categories, in addition to objectivity through measured values, the lecturer also assesses the global rating of student performance,(2) lecturer ratings also influenced by social values of students such as attitude and activeness, (3) lecturer ratings are based on pure benchmark values but can also be through class interval values. Meanwhile, student self-assessment is more stringent than lecturer assessment can be caused by several factors: (1) students lack confidence in assessing their performance, although some overestimate, (2) students are more concerned with the ability of knowledge and actual skills than the score, (3) students may be dishonest and more motivated to show weak areas in their learning process, (4) students fail to understand the instructions in the self-assessment questionnaire (Muth'im, 2016; Kirov et al., 2014; Andrade et al., 2009).

Student self-assessment is not different from lecturer assessment because: (1) academic value consists of a cognitive value, skill, and attitude, while student self-assessment only assesses cognitive and skill, but the proportion of attitude value in lecturer assessment does not affect only $15-20 \%$, (2) clinical experience and student intuition by the assessment process carried out by the lecturer, both the questions and the method. Student self-assessment differs from lecturer assessment because: (1) student self-assessment is subjective greater than objective, judging by variations in questionnaire answers, (2) standard lecturer assessment by looking at student learning outcomes, while student self-assessments are under-estimated and there are also overestimates (Kirov et al., 2014).

The qualified curricula and well implemented will be received positively by students and more likely to create a positive perception as well. When students assess their abilities are also influenced by perception when receiving lessons. Various reasons that arise that underlie perceptions include student character, personality, situations and conditions while studying and several other variables. Furthermore, positive perception will be increase student motivation to learning (Mukesh et al., 2018). By using repeated self-assessments, the learning objectives of all domains of education (knowledge, skills, and attitudes) can be easily calculated. This instrument is valid and reliable when done with the right technique. But self-assessment cannot stand alone still must be combined with the assessment of lecturers. Thus, this self-assessment cannot replace the teaching function structurally or procedurally, it only adds to the quality and value of the evaluation system that is already running (Raupach et al., 2012).

The limitation of this survey, the participants only involved students from the Faculty of Medicine at the University of Syiah Kuala, so the results of this survey could only be used at the institution. It may not be relevant to the self-assessment of medical students at other institutions. In general, the results of this study are very useful for the development of assessment systems in clinical rotation students. Student self-assessment has the opportunity to be a benchmark for the success of an institution if it is carried out objectively and honestly. In further research, we recommend conducting research with other assessment methods and discussing the advantages and disadvantages of student self-assessment and other assessment systems. It can also be made a comprehensive checklist of the student learning process so that lecturers and students have the same method of the assessment.

\section{Conclusion}

Student ability regarding the clinical skills by using self-assessment has many advantages and potential to be developed in evaluating student learning outcomes in clinical rotation of forensic medicine. However, because a student's self-assessment relies on experience and intuition, the results can lead to bias. In this survey, found the validity of student self-assessment not valid in determining the ability of clinical skills, it is influenced by several factors of objectivity and subjectivity of assessment both in terms of students and 
lecturers. Nevertheless, in general, the student self-assessment is relatively the same as the lecturer assessment, seen from the average score given is 3.40 versus 3.49. To support the increase in the validity of self-assessment, it requires a more comprehensive instrument that can make it easier for students to assess their ability of clinical skills.

\section{Acknowledgments}

The authors express the deepest thanks to the participants who took part in this survey.

\section{References}

Al Haqwi AI, Taha WS. 2015. Promoting excellence in teaching and learning in clinical education. J Taibah Univ Med Sci.10(1): 97-101.

Ameer Y, Maria G, Sonomal. Abbasi MH, Ali ML, Wajeeha. 2019. Medical students' perceptions regarding autopsy as an educational tool. PJMHS. 13(2): 361-364.

Andrade H, Valtcheva A. 2009. Promoting learning and achievement through self assessment.Theory Pract. 48: 12-19.

Fouche L, Bezuidenhout J, Adefuye AO. 2019. Improving the knowledge of clinical forensic medicine among mediacal graduates; Perspectives of community services doctors. AJHPE.11(3): 81-82.

Gopalakrishnan HN, Syukriani YF, Setiawati EP. 2016. Forensic expert opinion regarding clinical forensic medical practicein Indonesia and Malaysia. J Forensic Sci Med.2: 8590.

Khoiriyah U, Roberts C, Jorm C, Van Der Vleuten CPM. 2015. Enhancing student's learning in problem based learning: validation of a self assessment scale for active learning and critical thinking. BMC Med Educ. 15(140): 1-6.

Kirov D, Kazakova S, Kirilova J. 2014. Student's self assesment in preclinical and clinical education of prosthetic dentistry. J IMAB. 20: 575-577.

Kishor SC. 2014. Forensic medicine curriculum in medical schools of Malaysia-a review. Bangladesh J Med Educ. 5(1): 2-5.

Meilia PDI, Freeman MD, Herkutanto, Zeegers MP. 2020. A review of causal inference in forensic medicine. Forensic Sci Med Pathol.1-8.

Mukesh B, Sarika P, Amol K, Borde AN. 2018. Medical students perceptions regarding the curriculum in community medicine: a cross sectional study. Indian J Forensic Community Med. 5(1): 39-43.

Muth'im A. 2016. Does student self assessment assess a valid and reliable as teacher assessment?. Arab World English J. 7(1):123-139.

Perera HJM. 2013. An outcome based curriculum for postgraduate training in Forensic Medicine in Sri Lanka: four new learning outcomes. MLJSL. 1(2): 1-9.

Raupach T, Schierkirka S, Muncher C, Beißbarth T, Himmel W, Burckhardt G, et al. 2012. Piloting in outcome-based programme evaluation tool in undergraduate medical education. GMS Z Med Ausbild. 29. Doc44.

Schiekirka S, Reinhardt D, Helm S, Fabry G, Pukrop T, Anders S, et al. 2012. Student perceptions of evaluation in undergraduate medical education: A qualitative study from one medical school. BMC Med Educ. 12(45): 1-7.

Sharma R, Jain A, Gupta N, Garg S, Batta M, Dhir SK. 2016. Inpact of self assessment by students on their learning. Int J App Basic Med Res. 6: 226-229.

Spiller D. 2012. Assessment matters: self assessment and peer assessment. Waikato: The university of Waikato. 